\title{
Natural Resource Management Problems Of Coastal Areas And Small Islands In The Aru Island
}

\author{
Jantje Tjiptabudy ${ }^{1}$, Revency Vania Rugebregt ${ }^{2}$, S.S.Alfons ${ }^{3}$, Adonia I Laturette ${ }^{4}$, \\ Vica J. E Saiya ${ }^{5}$ \\ ${ }^{1}$ Faculty of Law, Pattimura University \\ Jln. Ir. M. Putuhena Kampus Poka, Ambon, 97233, Indonesia \\ Tel/Fax: +62-911-3825204 E-mail: jtjiptabudy@gmail.com \\ ${ }^{2}$ Faculty of Law, Pattimura University \\ Jln. Ir. M. Putuhena Kampus Poka, Ambon, 97233, Indonesia \\ Tel/Fax: +62-911-3825204 E-mail: revency_rugebregt@yahoo.com \\ ${ }^{3}$ Faculty of Law, Pattimura University \\ Jln. Ir. M. Putuhena Kampus Poka, Ambon, 97233, Indonesia \\ Tel/Fax: +62-911-3825204 E-mail: saartjealfons@gmail.com \\ ${ }^{4}$ Faculty of Law, Pattimura University \\ Jln. Ir. M. Putuhena Kampus Poka, Ambon, 97233, Indonesia \\ Tel/Fax: +62-911-3825204 E-mail: latturetedony@yahoo.com \\ ${ }^{5}$ Faculty of Law, Pattimura University \\ Jln. Ir. M. Putuhena Kampus Poka, Ambon, 97233, Indonesia \\ Tel/Fax: +62-911-3825204 E-mail: justitia_power@yahoo.com
}

\begin{abstract}
On the territory of Aru in the management of natural resources. 3 Last year a lot of the problems occur. This is because their licenses natural resources management provided by the government to investors who want control over land in this region, and explore them without regard to the ecosystem and the environment and indigenous people who live in it and in the end lead to conflict.
\end{abstract}

Keywords : Natural Resources Management Problems; Coastal area and Small Island

\section{INTRODUCTION}

The existence of small islands in the Maluku province have consequences on the diversity of regional economic conditions. The tendency of agglomeration economies that form the center of the development and the surrounding area creates wide disparities in areas far from the center, especially in the area of small islands, which generally have weaker 
access to any center. This condition is one factor that causes the difference in the capacity of each region, not just the economic aspects of the region but also on socio-cultural aspects and socio-political support decision-making processes at the regional level.

On the other hand the existence of small islands in the Maluku actually has a strong capacity of aspects of the availability of marine and coastal biological resources. High and diverse potential of coastal and marine biological resources did not necessarily support the dynamic development in each region. This condition is formed because of weak institutional systems support at the regional level, capacity utilization and weak management, are also not supported by the policies and capacities in the region to expand the utilization of marine and coastal biological resources, as well as the lack of support systems and regulation at the local level.

Physical consequences of small islands that are vulnerable to the threat of human activity and the potential for damage to natural as well as pressure on land development activities be important for efforts to save the environment of small islands. Efforts to increase regional capacity of small islands and rescue efforts require the utilization and management strategies oriented to improving the local economy and the region's economic aggregate and sustainable development in the area of small islands.

\section{PROBLEMS}

The problems faced by small islands in Maluku turned out to be wise by initiating efforts mentioned above. Conditional situation is the basis of the development of this paper. For the sake of it, then this article is focused on the overview of the potential, identification of issues and problems on small islands in the Moluccas and economic use strategy oriented community/region and strategic management of small islands in a sustainable manner.

\section{ANALYSIS AND DISSCUSSION \\ Coastal Zone Development Problems}

There are several problems that occur in the development of coastal and marine areas in Indonesia, among others, pollution, habitat degradation, overexploitation of natural resources, coastal erosion, the conversion of the designation of protected areas into other development, and natural disasters. 


\section{Pollution}

Marine pollution is the introduction of living creatures, substances, energy, and/or other components into the marine environment by human activities so that quality decreases to a certain level which causes the marine environment no longer in line with quality standards and/or functions. ${ }^{1}$

This pollution problem caused by human activities such as land clearing for agriculture, urban development and industry, logging and mining in the watershed (DAS). Clearings above as part of the agricultural activity has increased agricultural waste either solid or liquid that goes into the sea through the coastal waters and watersheds.

Municipal and industrial development is a source of sediment and pollution of coastal waters and the sea. The rapid development of settlements and cities has increased the number of both solid and liquid garbage that is a source of pollution of coastal and marine unwieldiness. Industrial and mining sectors that produce waste chemicals (such as cyanide, lead, nickel, chromium, etc.) are discarded in large quantities into the river potentially

\footnotetext{
1 Departemen Kelautan dan Perikanan R.I., Keputusan Menteri Kelautan dan Perikanan No. : Kep. 10/Men/2002 Tentang Pedoman Umum Perencanaan Pengelolaan Pesisir Terpadu. 2002.
}

contaminating coastal waters and marine, especially material cyanide-known toxins that are very dangerous.

Physical damage habitat for coastal and marine areas have resulted in a decrease in the quality of the ecosystem. This happens on mangrove ecosystems, coral reefs and seaweed or seagrass. Most habitats in coastal areas is due to human activities such as the conversion of mangrove forests for the benefit of settlements, infrastructure development, and fishing ponds. Indonesia has the largest tropical mangrove forest reserves in the world with about 3.8 million ha, or about $30-40 \%$ of the total world mangrove forest mangrove forests in Indonesia is concentrated in Papua and Maluku (71\%), Sumatra (16\%), Kalimantan (9\%) and Sulawesi $(2.5 \%)$. However, as a result of human activity, in the year 1970 - 1980, Indonesian mangrove forest area is reduced by about 700,000 ha for other land uses.

Other ecosystems suffered considerable damage in Indonesia is the coral reef ecosystem. From various research shows that of the 24 locations of coral reefs in Indonesia, $60 \%$ are in very good condition, $22 \%$ good, $33.5 \%$ moderate and $39 \%$ in a state of disrepair. According to the Ministry of Environment 
(1993) that $14 \%$ of coral reefs in Indonesia has reached alarming levels, $46 \%$ had suffered damage, $33 \%$ in good condition, and $7 \%$ is in good condition.

There are several factors that led to the destruction of coral reefs, among others: (1) mining rock for building materials, road, and decoration, (2) fishing with explosives, poisons, and fishing gear particular, (3) water pollution by the waste industry, agriculture and households, (4) deposition and increased turbidity due to soil erosion on land, excavation and mining, (5) over-exploitation of fishery resources reef.

Seagrass ecosystems are particularly vulnerable to environmental degradation caused by human activity. Some human activities that can mengrusak seagrass ecosystems are (1) the dredging and backfilling for residential development seafront, harbor, industry and navigation channels, (2) metal pollution industries, especially heavy metals, and organochlorine compounds, the disposal of organic waste, pollution by sewage industrial, agricultural, and oil. ${ }^{2}$

\footnotetext{
2 Bengen, D.G. (2000). Pengenalan dan Pengelolaan Ekosistem dan Sumber daya Pesisir (Prosiding Pelatihan Untuk Pelatih Pengelolaan Wilayah Pesisir Terpadu, Bogor 13-18 November 2000. Pusat Kajian Sumber daya Pesisir dan Lautan IPB.
}

Sources of pollution of coastal waters and oceans can be grouped into seven classes: industrial, residential wastewater (sewage), urban wastewater urban stormwater), mining, shipping (shipping), agriculture and aquaculture). Household pollution and pollution generated by the human activities and by industry. Household pollution occurs mainly in the coastal environment that is close to the settlement. Types of waste generated that there are two kinds of organic waste and inorganic waste. Growth in the number of people who Inhabit coastal areas and increasing tourism activities will Also increase of the number of bins and content of bacteria that can cause various damages to the coastal environment. Use of manure to fertilize the rice cultivation along the River watershed who are in it as well as industrial activities on land the which dump wastes into water bodies roommates are then Carried to the sea through coastal areas. This will enlarge the coastal areas of ecological pressures.

Source pollution from industrial wastes and ships along the coastal areas generally contain heavy metals. The content of heavy metals in waters is expected to continue to rise and will lead to soil erosion and leaching, the influx of industrial waste and the burning of fossil fuels to the waters and the atmosphere, as 
well as the release of the metal sedimentation of active mud directly. To maintain the balance of coastal ecosystems meal required the implementation of activities and development in sustainable and integrated land.

\section{Excessive resource exploitation}

There are few fisheries resources have been exploited excessively (overfishing), including shrimp, demersal fish, small palagis, and reef fish. It occurs mainly in areas with dense population, for example in the Malacca Strait, the northern coast of Java, Bali Strait, and South Sulawesi. The depletion of the stock of these resources, as well as overfishing are also triggered by economic activity either directly or indirectly damage the ecosystem and the environment so that the development of fishery resources disrupted. In addition, the lack of appreciation of human knowledge and to conserve fishery resources, such as shrimp, mangroves, coral reefs, and others.

\section{Abrasion Beach}

There are two factors that cause coastal erosion, namely: (1) the natural process (due to wave action on the beach Outdoor), (2) human activity. The human activity eg logging activities (HPH) or farm on land on which no heed to the concept of conservation has led to soil erosion and then the sediment was brought into the river and deposited in coastal areas. Other human activities are cut down or damage the ecosystem of the mangrove shoreline both for wood, charcoal raw materials, and in order to make a pond. Yet according to Bengen forest magrove the ecological functioning: (1) as a buffer waves and wind storms, coastal protection from abrasion, mudguard, and trapping sediments transported by the flow of surface water, (2) producing detritus (food for shrimp, crab, etc.) and minerals which can nourish the waters, (3) As the area nurshery ground, feeding ground and ground spawing various biota.

\section{Conversion of Protected Areas to Other}

\section{Uses.}

Today many once a shift in land use, for example of agricultural land into industrial land, property, offices, etc. that sometimes the friction policy without considering the ecological effect, but only consider the short-term economic gains. Similarly happened in the coastal region, a shift many coastal lands and even though the protected area into residential land, industrial, port, fishing pond, and tourism. As a result there is damage around the coastal ecosystems, especially mangrove 
ecosystems. If the mangrove ecosystem is damaged and even destroyed, then things will happen: (1) regeneration of the stock of fish and shrimp in danger, (2) occur marine pollution by pollutants that were previously bound by mangrove forests, (3) sedimentation in coastal waters, (4) shoreline erosion and salt intrusion.

\section{Natural disasters}

Natural disasters are natural events that have a negative impact on coastal and marine resources beyond human control. Several kinds of natural disasters that often occur in coastal areas and damage the coastal environment include sea level rise, the tsunami tidal wave, and ultra violet radiation

\section{Factors Affecting the Coastal Zone}

Some things that can influence the coastal region can be expressed as in that it:

\section{Added Population}

The human population is increasing exponentially, it is supported by advances in the field of health, and agriculture to promote human welfare. In 1998 the life support functions of biosphere should be divided on a 6 billion people. If fertility and mortality levels remain unchanged, world population will reach 40 billion people in the year 2010, if the baby is born this day alive. Indonesia with a population growth rate of $1.8 \%$ per year, then in 2010 the Indonesian population will reach 250 million people. This will acceleration and increasing demand to the needs of resource and environmental services. Meanwhile diminishing availability of natural land and is no longer sufficient, so that the next option is directed to use resources and coastal services to maintain and at the same time continue the existing growth. With the increasing population growth and the rapid development activities in coastal areas, for a variety of designation, the ecological pressure on ecosystems and coastal and marine resources will be increasing as well. Increasing this pressure will certainly be able to threaten the existence and survival of ecosystems and coastal resources, marine and small islands that are nearby.

\section{Human Activities}

With the rapid growth of both the growth of the world population, the development activities in coastal areas would be increased as well. Some of these activities, among others, coastal reclamation, industrial activity around the coastal areas, and others. Reclamation beach is an activity or process of repairing the area or areas of unused or useless into areas that 
can be exploited for human purposes, among others for agricultural land, housing, recreation and industry (Indonesian National Encyclopedia, 1990). The reclamation activities no matter how rigorous, it will change the conditions and environment of coastal ecosystems, and new artificial ecosystem is certainly not as good as natural. Therefore, the reclamation effort needs to be planned in such a way and carefully so that its presence does not change radically the original coastal ecosystems. It required a detailed spatial planning, environmental peneliatian for regional environmental impact assessment, hydro oceanography research, technical planning reclamation and infrastructure, drainage and sanitation planning and the planning of socio-economic and other development. $^{3}$

The influence of their industries sisekitar coastal areas will also result in changes in the carrying capacity of the coastal environment, among others decreasing gas levels of dissolved oxygen, phosphate and nitrate levels are high. Reduced levels of dissolved oxygen will cause living beings that are in the coastal ecosystem will be under pressure

\footnotetext{
${ }^{3}$ Hasmonel, Purwaningdyah, M.W dan Nurhayati, R. (2002). Reklamasi Pantai Dalam Hubungannya dengan Pendaftaran Tanah. Studi Kasus di Pantai Utara Jakarta. JSI, Vol. 12
}

ecologically, so it will threaten the survival of the ecosystem components.

Bodies of coastal areas is one place that is rich in nutrients, it is very important when viewed from biological resources. But for sustainability need to be considered waste from industries and other human activities are discharged into these waters, will damage the preservation of flora and fauna of coastal areas in the future, which can damage coastal ecosystem balance. ${ }^{4}$

\section{Coastal marine natural resources}

\section{management in the Aru Islands}

In Aru, indigenous peoples in conflict with PT Menara Inti group due to the 600 hectares of land that will be used as a sugar cane plantation Aru while the total area of 800 ha. Additionally in 1995, the country Haruku never conflict with PT Aneka Tambang conducting exploration activities on the area for their gold content. Which again is more worrying is the end of his term as Governor of Maluku, Alberth Karel Ralahalu more than 200 forest concessions, in the Aru Islands.

In some of the rules we perudang law, it has no guarantees for indigenous peoples in relation to the management of

\footnotetext{
${ }^{4}$ Simanjuntak, M. (1996). Kondisi Fosfat dan Nitrat di Perairan Teluk Banten.Inventarisasi dan Evaluasi Lingkungan Pesisir Oseanografi, Geologi, Biologi dan Ekologi. Pusat Kajian dan Pengembangan Oseanologi. LIPI, pg. 34
} 
coastal marine areas. For example the Act No. 31 of 2004 on Fisheries and Law No. 27 Year 2007 on the Management of Coastal Areas and Small Islands. In addition to these regulations, the rights of traditional fishermen is also still guaranteed by international maritime law (UNCLOS 1982) which has been ratified by the Indonesian government a few years ago.

However, in conditions of current Indonesian law, the mindset of policy makers we are not oriented towards sustainable development (sustainable development) is to maintain the environmental balance but more oriented to profit (benefit). Where development approach here is more priority to the needs and not a human rights approach to the destruction of the environment and natural ecosystems as well as a waiver of the rights of indigenous peoples over their natural resource management is an offense. We realize that with so much tension between the government, investors and indigenous peoples, in truth these three components must be placed as a subject in the management of a balanced and fair. With the consideration that if the destination country in the utilization of natural resources is the welfare of the people, then the government, indigenous peoples, and investors should be given a fair space. Figuring that if the rights of indigenous peoples are the owners of natural resources, the natural resources owned an investment capital while the entrepreneur or investor capital investment is, so that there should be a bargaining position and the balance between the two. Many people assume that customary law is the law of the ancient and ancestral traditions just load times ago and applied up to now and the static nature. However, the author would like to say here that customary law is the law that is dynamic and evolving appropriate time. In society there is a new tradition of indigenous customary law is made due to the times and modern culture, such as the right factual according R.Z.Titahelu, is newly created due to the demands and needs of indigenous people so that there is a change. Namely the right to crop planting seaweed. But also can not deny that there are people who also do not require any change or any other customary law communities that are disadvantaged because of the existence of his rights had already taken over.

In 2010, the Aru Islands Regent issued the license in principle 'for the conversion of natural forests to plantations in the Aru Islands. This permit is supported by the Governor of Maluku, which issued a 
'Letter of Recommendation to the Minister for Release of Forest Zone in July 2011. Subsequently, in February 2013, the Ministry of Forestry of Indonesia to allocate' forest 'for 19 of the 28 companies that make up the consortium of PT. The Tower Group. A year later, on February 6, 2014..$^{5}$

In Maluku, the then Governor, Saut Sitomorang, also allow the construction of a sugar plantation in the same areas. Most recently, in June 2015, the Minister of Agriculture announced that the State has set three locations for the development of industrial sugar cane plantations and processing facilities in Indonesia. Relating this there have been marginaze freedoms of indigenous communities where there has been a violation of the rights of indigenous peoples Aru on more than 50 percent of their traditional territories and sources of livelihood contained therein related to the construction of this large sugar cane plantations. This area, which covers an area of approximately 484500 hectares and most island in Aru Islands archipelago, has been given to the Tower Group as a concession. This area is equal to more than half the traditional territories

\footnotetext{
${ }^{5}$ Aliansi Masyarakat Adat Nusantara. (2015). Forest People Program, Permohonan untuk Pertimbangan atas Situasi Masyarakat Adat Kepulauan Aru, Indonesia, di bawah Prosedur Peringatan Dini dan Aksi Mendesak Komite Penghapusan Diskriminasi Rasia. Jakarta: Aman.
}

of indigenous peoples Aru and covers more than half of the 179 villages.

Therefore, it is an urgent situation that is fully in accordance with the criteria adopted by the Committee in connection with the early warning procedure and the urgency of action. In addition to large scale and "encroachment on the traditional lands of indigenous peoples, including for the purpose of exploitation of natural resources, and it is also a serious situation that requires immediate attention to prevent or limit the scale or number of serious violations of the Convention.

If in reviewing backward since 1989, PT. Budhi Real (Djajanti Group), has obtained a concession of forest concessions (HPH) on the island of Wokam and Maikoor, covering an area of 98,000 hectares. Companies harvesting timber from natural forests have ended in 2004. Another company that has been active in the Aru Islands is PT. Utama Lestari Kirana. A per company per coffee plantations that have earned Timber Utilization Permits (IPK) of land clearing (land clearing) in 2011 and 2012. However, to date there is no coffee plantations in the former location of the company. The dominance of natural forest wealth asserted animals that live in it and used by the community. Settlements in the 
Aru Islands mostly in coastal areas, is divided into seven districts and home to more than 84 thousand inhabitants. Aru Islands consists of small islands, mostly of less than 200,000 hectares, except Trangan Island. Changes in the landscape will have a direct impact on inland water ecosystems and sea. Ecologically level of fresh water supply and diversity of flora and fauna will decline. While at the social level, also resulted in changes in the pattern of income and social fabric of Indigenous Peoples in the Aru Islands. Fact Sheet Aru Islands shown that there are three large companies that have a license management of forest area in the Aru Islands and its subsidiaries.

With an area of 800 thousand hectares of the take over, but almost entirely been made in natural resource exploration center inhumane. Moreover, parts of the Aru Islands are small islands where exploitation of small islands at risk 20 times greater than the exploitation on the big island. The small island has a water circulation system which is very fast and fragmented. So that between one and the other islands can not affect each other. If the forest in small islands Aru Islands exhausted, then it is certain there will be about 84 thousand inhabitants Aru Islands communities that lose their water sources.
Deprivation of customary rights of indigenous peoples in the Aru Islands are also in violation of the policies issued by the Constitutional Court (MK) in 2012. The Constitutional Court 35 of 2012 clearly stated that the indigenous forest is not a state forest.

Given this decision it is clear that indigenous territories, especially in the Aru Islands are entitled to recognition from all circles. The rejection of the excessive exploration has become a threat to the environmental damage and the customary law communities of their rights over the natural resources that exist. And although indigenous peoples have established SASI customary to 80 percent of the region in Aru to reject the entry of the company and dated 10 April 2010 In 2014 the Ministry has declared the cancellation of the license in principle reserve forest area Aru yet, but that does not mean that policy making Aru free from threats. Based on the above people no longer have the freedom to conduct its activities due to the ownership by individuals, private and above. So since the beginning of the discussion of law coastal areas management this is already happening rejection, so that eventually the fishing communities and other community groups filed a submission to the Constitutional Court materiel test. Very 
fitting as in said Karen Lebacqz that is causing injustice exists because decisions in the field of economic, social and cultural as well as other decisions. It looks apparent in government decisions to grant management rights to the private sector and individuals.

In speaking of justice, where it has been seen that indigenous peoples should be protected by constitutional rights enshrined in article 18 B Constitution NRI 1945 and various regulations of other legislation, it proves that the value of freedom in obtaining the right itself is very difficult because it will be hindered by various government regulations are not partial to indigenous peoples. In this case the government still think that they own the top notch and the public have unequal position. Though Equality (equality) are pairs of freedom inherent in every modern concept of justice. Equality between individuals based on the assumption that all people, as human beings, have the same human dignity (equal). Therefore, all people have the same rights to organize and protect life through a variety of businesses. Values of equality which is the main and equality in terms of freedom.

Then comes another equality in line with the scope of the free life of every person in the life of society. Equality in twos at a time, ie, achievement equitable to all people as human beings and equitable form of appreciation of it in various scope of human life Robert M. Veatch argued that equality in the concept of justice include: equality of moral worth (price equality equality of opportunity (equality and opportunity to be able to meet basic needs), equality of outcome (equality in what is produced). Kai Nielsen adds one more equality, namely equities bear the burden of life together in society.

According Meshach, that freedom is a value associated with the recognition and appreciation of the existence of an autonomous everyone in the community. While equality is a value that governs the recognition and appreciation existential in relationships between people inside. community. In this case, the function of the value of justice that regulate relations between individuals in the community look in the value of equality of liberty. Freedom itself to be governed by the value of equality so that the good of all members of society. Freedom without equality, humans will return to the law of the jungle. While equality is not to bring in the maximum freedom for all members of society, not equality in the concept of justice. The dynamics of relations between freedom and equality of individuals in parallel with 
the dynamics of community relations. Individuals that are in the realm of freedom and the people that are in the area of equality. Overemphasis on one of them will produce a life threat human, individuals and community

\section{CONCLUSION}

The ideology of legal centralism (legal centralism) tend to marginalize social capital (social capital), the image and environmental ethics, religious system, the principles and norms of customary law that reflects the wisdom of the environment (ecological wisdom) local communities. In addition, the national development capital also degrade natural resources (ecological capital) as a result of development activities are patterned exploitative.

Therefore, in order to realize the procedure of making good laws (good law making governance), then the future agenda should the government and the legislature are: Conducting the review again (review) of all laws that do not reflect justice, democracy, and sustainability replaced with good legal product environmentally especially referring to the principles of sovereignty environment leading to green and green constitution legislator.

To that end, in the wisdom needed by the government in making policy and legal arrangements, which accommodates all matters concerning the interests of the community at large. The Central Government should make a new law that is unified in this case to accommodate the local wisdom of indigenous peoples as a form of recognition of the State of the authority in natural resource management.

\section{BIBLIOGRAFY}

Aliansi Masyarakat Adat Nusantara. (2015). Forest People Program, Permohonan untuk Pertimbangan atas Situasi Masyarakat Adat Kepulauan Aru, Indonesia, di bawah Prosedur Peringatan Dini dan Aksi Mendesak Komite Penghapusan.

Bengen, D.G. (2000). Pengenalan dan Pengelolaan Ekosistem dan Sumber daya Pesisir (Prosiding Pelatihan Untuk Pelatih Pengelolaan Wilayah Pesisir Terpadu, Bogor 13-18 November 2000. Pusat Kajian Sumber daya Pesisir dan Lautan IPB. Departemen Kelautan dan Perikanan R.I., Keputusan Menteri Kelautan dan Perikanan No. : Kep. 10/Men/2002 Tentang Pedoman Umum Perencanaan Pengelolaan Pesisir Terpadu. 2002.

Hasmonel, Purwaningdyah, M.W dan

Nurhayati, R. (2002). "Reklamasi

Pantai Dalam Hubungannya dengan 
Pendaftaran Tanah. Studi Kasus di Pantai Utara Jakarta”.JSI. Vol 12

Simanjuntak, M. (1996). Kondisi Fosfat dan Nitrat di Perairan Teluk Banten.Inventarisasi dan Evaluasi Lingkungan Pesisir Oseanografi, Geologi, Biologi dan Ekologi. Pusat Kajian dan Pengembangan Oseanologi. LIPI. 